\title{
Pembelajaran Sejarah Berbasis Kurikulum 2013 di SMA Kotamadya Jakarta Timur
}

\author{
Zia Ulhaq, Tuti Nuriah, Murni Winarsih \\ SMA Negeri 42 Jakarta \\ belajarsejarah42@yahoo.com
}

\begin{abstract}
This study aims to obtain a systematic description of the implementation of the 2013 curriculum on learning history in high school East Jakarta Municipality. The research location is in SMAN 81 Jakarta and SMA Angkasa 1 Jakarta. This research uses qualitative approach with method of grounded theory of research data. The results showed that the understanding of teachers in the grassroot on various learning concepts both in terms of planning, implementation to evaluation is quite low. From the planning, implementation and assessment, only the implementation of learning that can be implemented by teachers in the research location, while planning and assessment is not implemented optimally. showing by teachers not making the completely lesson plan, teachers assume two subjects of history in secondary school (history of Indonesia and history) are the same subjects, as well as the use of attitude assessment techniques that only use observation techniques. In addition, it was also found out that historical learning in the research sites has been based on commucication and information technology in accordance with the saintifik approach in the curriculum of 2013.
\end{abstract}

Keywords: Instructional History, curriculum 2013, secondary school

Penelitian ini bertujuan untuk memperoleh gambaran aktual sistematis mengenai implementasi kurikulum 2013 pada pembelajaran sejarah di SMA Kotamadya Jakarta Timur. Lokasi penelitian berada di SMAN 81 Jakarta dan SMA Angkasa 1 Jakarta. Penelitian ini menggunakan pendekatan kualitatif dengan metode analisis teoritisasi data. Hasil penelitian menunjukan bahwa pemahaman guru-guru di lapangan mengenai berbagai konsep pembelajaran baik dari segi perencanaan, pelaksanaan hingga evaluasi masih rendah, dari bidang perencanaan, pelaksanaan dan penilaian, hanya bidang pelaksanaan pembelajaran yang dapat diimplementasikan oleh guru di lokasi penelitian, sedangkan perencanaan dan penilaian tidak terimplementasikan secara optimal, ditandai dengan guru tidak membuat perangkat secara lengkap, guru beranggapan dua mata pelajaran sejarah di SMA yaitu sejarah Indonesia dan sejarah adalah mata pelajaran yang sama, serta penggunaan teknik penilaian sikap yang hanya menggunakan teknik observasi. Selain itu ditemukan pula hasil bahwa pembelajaran sejarah di lokasi penelitian telah berbasis TIK serta sesuai dengan pendekatan saintifik dalam kurikulum 2013. Penulisan hasil belajar di lokasi penelitian menggunakan sistem yang terkomputerisasi, meskipun salah satu lokasi penelitian (SMAN 81 Jakarta) menggunakan sistem E-Rapor yang tersinkronisasi dengan Dapodik sedangkan pada lokasi penelitian 2 (SMAN Angkasa 1 Jakarta) aplikasi yang digunakan tidak terhubung langsung dengan Dapodik.

Kata kunci: Pembelajaran sejarah, kurikulum 2013, sekolah menengah atas

\section{PENDAHULUAN}

Pemerintah Indonesia, melalui Kementerian Pendidikan Dasar dan Menengah menggelar dan menetapkan sejarah sebagai sebuah mata pelajaran yang penting dalam kurikulum 2013, khususnya bagi pendidikan tingkat menengah atas (SMA-sederajat). Mata pelajaran Sejarah Indonesia pada tingkat SMA merupakan sebuah mata pelajaran kelompok wajib A, 
yang berarti mata pelajaran tersebut wajib diambil oleh seluruh jenis sekolah menengah tingkat atas yang berada di lingkup Kementerian Pendidikan Dasar dan Menengah dan Kementerian Agama. Selain menjadi mata pelajaran wajib, terdapat pula mata pelajaran sejarah yang termasuk dalam kelompok peminatan ilmu-ilmu sosial, bahasa dan menjadi pelajaran lintas minat.

Pembagian mata pelajaran sejarah Indonesia dan sejarah tidaklah dikenal dalam kurikulum sebelumnya (KTSP). Pemisahan mata pelajaran tersebut barulah dilakukan dalam Kurikulum 2013. Berdasarkan kelompoknya, Sejarah Indonesia merupakan pelajaran yang diberikan kepada seluruh siswa, maka seringkali disebut sebagai sejarah wajib. Sedangkan mata pelajaran sejarah, hanya diberikan kepada para siswa yang berada pada penjurusan IPS di SMA, atau diberikan kepada jurusan lain (IPA atau Bahasa) sebagai mata pelajaran lintas minat. Dua mata pelajaran ini, memiliki tujuan dan kedudukan yang berbeda satu sama lain.

Perbedaan mata pelajaran antara sejarah dan sejarah Indonesia menimbulkan pertanyaan apakah tujuan belajar dari kedua mata pelajaran tersebut dapat tercapai dan dilakukan dengan baik, ataukah justru hanya terdapat perbedaan yang sangat sedikit atau bahkan tidak ada perbedaannya satu sama lain, beberapa guru bahkan ada yang menggabungkan materi pembahasan antara mata pelajaran sejarah Indonesia dengan mata pelajaran sejarah, dengan alasan materi pelajaran yang sama antara dua mata pelajaran tersebut.

Masalah berikutnya adalah mengenai implementasi kurikulum 2013, berdasarkan observasi awal ditemukan guru masih mengalami kesulitan dalam mengimplementasikan kurikulum 2013. Kesulitan guru mengadaptasi beberapa pembaharuan dalam pembelajaran sejarah berbasis kurikulum 2013 revisi terbaru, antara lain dalam bentuk penyusunan perencanaan pembelajaran, yang dimulai dari analisis SKL-KI-Indikator hingga kepada rencana pelaksanaan pembelajaran (RPP), penerapan pendekatan saintifik dalam pembelajaran, penerapan model-model pembelajaran dalam pelaksanaan pembelajaran, serta penerapan penilaian yang berbasis penilaian autentik dengan penilaian 3 ranah (sikap, ketrampilan, pengetahuan).

Fungsi dan tujuan pendidikan sejarah tidak diragukan lagi manfaatnya bagi pembangunan sebuah bangsa. Sebagai sebuah mata pelajaran di sekolah, sejarah tidak lagi terpisah dari nilai-nilai dan peneladanan dari tokoh-tokoh sebuah bangsa dan negara yang diharapkan akan diteruskan oleh para generasi berikutnya.

Pendidikan sejarah merupakan media pendidikan yang paling ampuh untuk memperkenalkan kepada peserta didik tentang bangsanya di masa 
lampau. Hassan (2012 : 35) mengemukakan setidaknya ada dua tujuan penting dari pendidikan sejarah, pertama sebagai media yang mampu mengembangkan potensi peserta didik untuk mengenal nilai-nilai bangsa yang terus bertahan, berubah dan menjadi milik bangsa masa kini. Melalui pendidikan sejarah, peserta didik belajar mengenal bangsanya dan dirinya. Tujuan yang kedua adalah sebagai wahana pendidikan untuk mengembangkan disiplin ilmu sejarah.

Hunt (2007:7) menjelaskan menurut hasil kerja dari History Working Group, ada sembilan tujuan dari pembelajaran sejarah di sekolah, antara lain adalah : (1) Untuk memahami masa kini dalam konteks masa lalu, (2) Untuk membangkitkan minat dari masa lalu, (3) Untuk memberikan identitas dari para siswa (kebangsaan), (4) Untuk membantu memberikan murid pemahaman tentang akar dan warisan budaya mereka, (5) Untuk berkontribusi terhadap pemahaman dan pengetahuan peserta didik mengenai negara dan kebudayaan berbeda dalam dunia modern, (6) Untuk melatih pikiran dengan studi disiplin ilmu sejarah, (7) Untuk memperkenalkan siswa metodologi sejarah yang khas, (8) Untuk mendorong bagian lain dari kurikulum, (9) Untuk mempersiapkan siswa menuju kehidupan dewasa.

Kesembilan tujuan dari belajar sejarah di sekolah tersebut, memuat baik dimensi kegunaan belajar sejarah dalam tataran praktis, yaitu sebagai media membangun identitas bangsanya, sekaligus dimensi melatih siswa dalam kemampuan khas dari disiplin ilmu sejarah itu sendiri.

Dokumen kurikulum 2013 (2012:2) menyatakan kurikulum adalah suatu respon pendidikan terhadap kebutuhan masyarakat dan bangsa dalam membangun generasi muda bangsanya. Secara pedagogis, kurikulum adalah rancangan pendidikan yang memberi kesempatan untuk peserta didik mengembangkan potensi dirinya dalam suatu suasana belajar yang menyenangkan dan sesuai dengan kemampuan dirinya untuk memiliki kualitas yang diinginkan masyarakat dan bangsanya. Kurikulum 2013 adalah kurikulum berbasis kompetensi. Kurikulum berbasis kompetensi adalah "outcomes-based curriculum" dan oleh karena itu pengembangan kurikulum diarahkan pada pencapaian kompetensi yang dirumuskan dari SKL. Demikian pula penilaian hasil belajar dan hasil kurikulum diukur dari pencapaian kompetensi (Kemendikbud 2012:7)

Penelitian ini ingin melihat bagaimana keadaan di lapangan menyangkut pembelajaran sejarah, khususnya menyangkut bagaimana guru melakukan pembelajaran sejarah dan sejarah Indonesia pada guru yang sama di tingkat kelas X dan XI berbasis kurikulum 2013. Sebagai sebuah mata pelajaran yang berbeda, peneliti ingin sekali melihat dan membangun 
pemahaman dari kenyataan di lapangan mengenai pembagian dari dua mata pelajaran tersebut, dari segi perencanaan, pelaksanaan dan evaluasinya.

Fenomena ini penting diteliti karena dengan mengetahui keadaan sebenarnya di lapangan, para akademisi, praktisi dan para pemegang kebijakan dapat melihat proses dari jalannya pembelajaran sejarah di level Grounded yang secara massif dilaksanakan di seluruh sekolah. Permasalahan utama yang hendak dilihat ada dua proposisi, yaitu proses pembelajaran sejarah dan sejarah Indonesia di kelas XI dari sisi pengimplementasian kurikulum 2013 dan yang kedua adalah persepsi dan pandangan guru sebagai pelaksana kebijakan kurikulum 2013 terhadap berbagai perubahan dalam konsep pembelajaran sejarah. Permasalahan demikian, menurut peneliti, paling tepat diteliti menggunakan pendekatan kualitatif.

\section{METODE}

Peneltian ini menggunakan pendekatan kualitatif dengan metode Grounded Theory. Data dalam penelitian ini berupa proses pembelajaran sejarah dan sumber data diperoleh melalui wawancara, observasi dan telaah dokumen. Data yang dikumpulkan kemudian dilakukan coding dengan menggunakan prinsip pengkodean berbuka (open coding) dan pengkodean berporos (Axial Coding) untuk kemudian dianalisis dan dilakukan teoritisasi data. hasil analisis ini kemudian dijelaskan dalam bentuk deskriptif analisis untuk dilaporkan di hadapan penguji.

Proses pengumpulan data dalam penelitian ini dilaksanakan dengan cara observasi, wawancara dan telaah dokumen. Observasi dilakukan pada proses pembelajaran di kelas, keseharian guru, MGMP tingkat sekolah dan pada saat evaluasi pembelajaran, peneliti juga melakukan telaah dokumen berupa penelaahan terhadap perencanaan guru, program kerja guru mata pelajaran sejarah dan sejarah Indonesia serta melihat pada pencapaian nilai pembelajaran para siswa yang tertuang di buku nilai. untuk mengobservasi nilai sikap, peneliti melakukan studi dokumentasi terhadap jurnal penilaian sikap yang dimiliki guru.

Dalam pengambilan data secara wawancara sumber data dipilih secara purposive sampling. pemilihan cara Purposive dikarenakan tema penelitian yang cukup spesifik mengenai pembelajaran sejarah, maka informan penelitian yang di maksud adalah pembelajar (Guru pengampu mata Pelajaran sejarah) yang berjumlah sebanyak 5 orang dengan komposisi 3 orang di lokasi penelitian 1 (SMAN 81 Jakarta) dan 2 orang di lokasi penelitian 2 (SMA Angkasa 1 Jakarta).

Hasil dari proses observasi serta wawancara di lapangan kemudian ditambahkan dengan analisis awal oleh peneliti sebelum turun ke lokasi penelitian maka kemudian dilakukan analisis data dengan melakukan 
pengkodean (Coding) yang berpatokan pada pedoman penelitian dengan metode Grounded Theory. selama berlangsungnya pengambilan data dan analisis data, peneliti juga terus menjaga keabsahan data dengan menerapkan validasi dan reliabilitas dalam penelitian kualitatif. Hasil analisis data kemudian ditarik kesimpulan mengenai pengalaman dan persepsi dari para guru SMA di kotamadya Jakarta Timur.

Proses analisis data yang akan dilakukan adalah dengan menyusun dan menyiapkan berbagai data hasil wawancara (transkrip) dengan guru dan kepala sekolah serta dengan para siswa mengenai pembelajaran sejarah di kelas, kemudian membaca seluruh hasil observasi baik dari observasi awal hingga akhir dan melakukan coding dari hasil pengambilan data tersebut sesuai dengan kategori-kategori yang akan dibuat kemudian oleh peneliti.

Hasil dari analisis data yang dilakukan peneliti adalah kemudian sebuah kesimpulan dan sintesa yang akan dituliskan dengan menggunakan prinsip-prinsip yang mudah dimengerti, pengkodean hasil pengambilan data menggunakan cara menggolongkan berdasarkan konsep-konsep yang ditemukan dalam fenomena pembelajaran di lokasi penelitian, peneliti akan melihat konsep dalam kategori mengenai pembelajaran sejarah secara terpisah, yang pertama mengenai perencanaan pembelajaran, yang kedua adalah pelaksanaan pembelajaran, evaluasi pembelajaran dan pembuatan pelaporan hasil belajar, penggolongan tersebut didasarkan pada subfokus penelitian yang akan diteliti yang kemudian diterjemahkan menjadi kategori yang akan dipakai dalam proses pengkodean.

Pemeriksaan keabsahan data dalam penelitian ini dengan menggunakan teknik validasi dan reliabilitas. Validasi yang digunakan adalah dengan triangulasi sumber, member checking, menulis deksripsi yang tebal dan kaya serta ulasan dengan teman sejawat. Reliabilitas dalam penelitian ini menggunakan teknik prosedur re-checking yang mengharuskan peneliti menulis ulang catatan lapangan dan transkrip wawancara sehingga mengurangi tingkat kealpaan dan yang kedua dengan variasi pengumpulan data.

\section{HASIL}

\section{Perencanaan Pembelajaran Sejarah dan Sejarah Indonesia}

Dalam implementasi kurikulum 2013, pembuatan perangkat pembelajaran merupakan komponen penting dalam persiapan guru sebelum mengajar, pembuatan dan penggunaan perangkat yang baik, dapat memudahkan guru dalam memetakan pelaksanaan pembelajaran dalam rentang waktu tahun ajaran berjalan. 
Perangkat pembelajaran dalam kurikulum 2013 memiliki alur dan tata langkah penyusunan bagi seorang guru, Peneliti melihat beberapa komponen perangkat berikut urutan yang dibuat guru untuk kelengkapan administrasi pembelajarannya atau disebut juga sebagai perangkat pembelajaran, sumber tabel ini diambil dari telaah dokumen pelatihan kurikulum 2013 yang diselenggarakan oleh LPMP DKI Jakarta untuk guruguru di lingkup Dinas Pendidikan DKI Jakarta, termasuk di dalamnya Jakarta Timur, langkah tersebut disusun secara berurutan antara lain :

Tabel 1.

Susunan perangkat pembelajaran pada kurikulum 2013 (LPMP 2015)

\begin{tabular}{|c|c|c|c|}
\hline No. & Langkah Pembuatan & Hasil Dokumen & Keterangan \\
\hline 1. & $\begin{array}{l}\text { Analisis SKL, KI-KD } \\
\text { dan Silabus }\end{array}$ & $\begin{array}{l}\text { Analisis } \\
\text { keterkaitan KI- } \\
\text { KD }\end{array}$ & $\begin{array}{l}\text { Mapel Sejarah Indonesia IPK } \\
\text { telah disusun, sedangkan } \\
\text { IPK Sejarah disusun oleh } \\
\text { guru mapel }\end{array}$ \\
\hline 2. & $\begin{array}{l}\text { Rumusan } \\
\text { Penyusunan IPK }\end{array}$ & Rumusan IPK & \\
\hline 3. & $\begin{array}{l}\text { Analisis Buku } \\
\text { Pelajaran }\end{array}$ & $\begin{array}{l}\text { Format Analisis } \\
\text { buku }\end{array}$ & Buku guru \& buku siswa \\
\hline 4. & $\begin{array}{l}\text { Penyusunan } \\
\text { Program Tahunan } \\
\text { dan Program } \\
\text { Semester } \\
\end{array}$ & $\begin{array}{ll}\text { Program } \\
\text { Tahunan } \\
\text { - } \\
\text { Program } \\
\text { Semester } \\
\end{array}$ & $\begin{array}{l}\text { Sebelum disusun prota- } \\
\text { prosem diperlukan adanya } \\
\text { analisis waktu }\end{array}$ \\
\hline 4. & $\begin{array}{l}\text { Analisis model } \\
\text { pembelajaran }\end{array}$ & $\begin{array}{l}\text { Pemilihan } \\
\text { model } \\
\text { pembelajaran }\end{array}$ & \\
\hline 5. & $\begin{array}{l}\text { Pembuatan pedoman } \\
\text { penilaian }\end{array}$ & $\begin{array}{ll}\text { - } & \text { Kisi-kisi soal } \\
\text { - } & \text { Soal } \\
\text { - } & \text { Pedoman } \\
& \text { penskoran } \\
\text { - } & \text { Rencana } \\
& \text { program } \\
\text { remedial }\end{array}$ & $\begin{array}{l}\text { Beberapa item digabungkan } \\
\text { dalam RPP }\end{array}$ \\
\hline 6. & Pembuatan RPP & $\begin{array}{ll}\text { RPP per } \\
\text { kompetensi } \\
\text { dasar }\end{array}$ & \\
\hline 7. & $\begin{array}{l}\text { Pengolahan } \\
\text { penilaian }\end{array}$ & - Buku NIlai & \\
\hline
\end{tabular}


Penelitian ini menemukan gambaran mengenai komponen perencanaan yang dibuat para guru di lokasi penelitian, untuk penyajian data, peneliti mengemukakan dalam bentuk tabel sebagai berikut :

Tabel 2.

Kelengkapan perangkat pembelajaran guru mapel Sejarah Indonesia TA 2016/2017

\begin{tabular}{|c|c|c|c|c|c|c|c|c|c|}
\hline No. & Subjek & 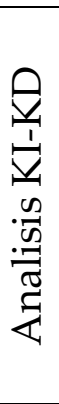 & 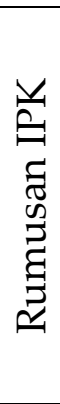 & 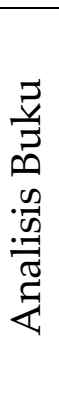 & 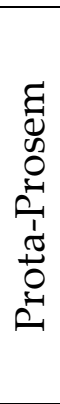 & 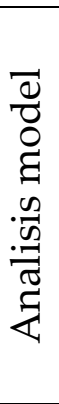 & $\hat{\curvearrowright}$ & 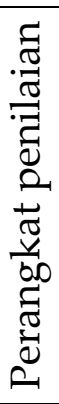 & TP. \\
\hline 1. & Informan inti 1(81) & $\mathrm{V}$ & $\mathrm{V}$ & V & $\mathrm{V}$ & $\mathrm{V}$ & V & V & 2016/2017 \\
\hline 2. & Informan inti $2(81)$ & & - & - & - & $\mathrm{V}$ & $\mathrm{V}$ & $\mathrm{V}$ & $2016 / 2017$ \\
\hline 3. & Informan inti 3 (81) & - & & - & - & V & $\mathrm{V}$ & $\mathrm{V}$ & $2016 / 2017$ \\
\hline 4. & Informan inti 4 (Ang) & - & - & - & $\mathrm{V}$ & - & V & V & $2016 / 2017$ \\
\hline 5. & Informan inti 5 (Ang) & - & - & - & - & - & V & $\mathrm{V}$ & $2016 / 2017$ \\
\hline
\end{tabular}

keterangan $: \mathrm{v}=$ membuat, $-=$ tidak membuat

Berdasarkan temuan penelitian peneliti menganalisa, sebenarnya pemahaman guru-guru di lokasi penelitian mengenai perencanaan pembelajaran yang diamanatkan oleh kurikulum 2013 masih cukup rendah, hal ini terlihat dari berbagai jawaban dan bukti dokumen yang tidak mendukung adanya pemahaman mendalam mengenai perangkat pembelajaran atau perencanaan pembelajaran yang ideal sesuai kurikulum 2013. Para guru di lokasi penelitian akan melengkapi seluruh administrasi pembelajaran lebih dikarenakan adanya dorongan dan tekanan dari pihak manajemen sekolah untuk disupervisi atau dikumpulkan, atau bahkan yang lebih kuat dorongannya adalah karena adanya momen akreditasi sekolah yang mensyaratkan kelengkapan administrasi pembelajaran bagi para gurunya.

Tidak ditemukan juga adanya perbedaan metode penyusunan perangkat pembelajaran atau perencanaan antara mata pelajaran sejarah dan Sejarah Indonesia, satu-satunya perbedaan yang ditemukan adalah mengenai tersedianya sumber belajar yang lebih lengkap, yaitu lebih banyaknya sumber belajar dari pemerintah tentang mata pelajaran Sejarah Indonesia dibandingkan dengan mata pelajaran sejarah. 


\section{Pelaksanaan Pembelajaran Sejarah dan Sejarah Indonesia}

Mengenai pelaksanaan pembelajaran sejarah berbasis kurikulum 2013, peneliti menemukan bahwa pendekatan saintifik sudah diterapkan dalam pelaksanaan pembelajaran di kelas oleh para informan, bukti yang mendukung telah dilaksanakannya pendekatan saintifik antara lain adalah observasi pelaksanaan pembelajaran di kelas telah mengacu pada prinsipprinsip pendekatan saintifik antara lain :

1) Peserta didik difasilitasi untuk mencari tahu;

2) Peserta didik belajar dari berbagai sumber belajar;

3) Proses pembelajaran menggunakan pendekatan ilmiah;

4) Pembelajaran berbasis kompetensi;

5) Pembelajaran yang menekankan pada jawaban divergen yang memiliki kebenaran multi dimensi;

6) Pembelajaran berbasis keterampilan aplikatif;

7) Pembelajaran yang menerapkan nilai-nilai dengan memberi keteladanan (ing ngarso sung tulodo), membangun kemauan (ing madyo mangun karso), dan mengembangkan kreativitas peserta didik dalam proses pembelajaran (tut wuri handayani);

8) Pemanfaatan teknologi informasi dan komunikasi untuk meningkatkan efisiensi dan efektivitas pembelajaran;

Walaupun ada beberapa prinsip pembelajaran dalam pendekatan saintifik yang tidak ditemukan dalam observasi di kelas, tetapi mayoritas prinsip pendekatan saintifik telah diamati dan ditemukan oleh peneliti.

Pada penelitian ini, peneliti menemukan bahwa guru-guru di lokasi penelitian selalu berupaya mendudukan peran sebagai fasilitator yang berusaha memunculkan peran belajar dari para siswa secara lebih aktif. Aktivitas pembelajaran didominasi dengan adanya diskusi kelompok, pembagian kelompok dilakukan oleh guru maupun dari siswa sendiri berdasarkan nomor urut absen. Pada titik ini, peneliti melihat adanya kesesuaian aktivitas sesuai dengan urutan logis $5 \mathrm{M}$ atau pendekatan saintifik dengan pembelajaran di kelas yang diterapkan oleh guru-guru di lokasi penelitian.

Model pembelajaran dalam kurikulum 2013 merupakan salah satu komponen yang dikenalkan dan diterapkan dalam kurikulum 2013. beberapa model yang dikenalkan merupakan bentuk penerapan dari pendekatan saintifik yang didalamnya mencakup urutan logis pengorganisasian pengalaman belajar siswa secara langsung.

Model pembelajaran yang diterapkan oleh guru di lokasi penelitian tidak banyak yang akan dibahas oleh peneliti, hal tersebut dikarenakan ternyata, pemahaman guru-guru di lokasi peneltian mengenai model pembelajaran yang diterapkan dalam kurikulum 2013 sangat rendah, 
perbedaan istilah dan banyaknya nomenklatur yang digunakan dalam kurikulum 2013 mengakibatkan seringnya tertukar istilah satu dengan yang lain, hal tersebut sangat terlihat dalam proses wawancara yang dilakukan peneliti.

Terkait dengan pembelajaran yang berbasis teknologi informasi, para guru di lokasi penelitian telah cukup terbiasa dengan mempraktekan pembelajaran berbasis IT, bahkan pada SMA Angkasa 1 Jakarta, handphone yang dapat terkoneksi dengan internet dapat dijadikan sumber belajar ketika berada di kelas. Guru-guru di lokasi penelitian berpendapat bahwa handphone dan internet cukup membantu secara efektif untuk para siswa mengakses sumber belajar secara langsung dengan mudah.

\section{Evaluasi Pembelajaran Sejarah dan Sejarah Indonesia}

Dalam implementasi kurikulum 2013, penilaian merupakan salah satu komponen pembelajaran yang banyak membingungkan para guru di lokasi penelitian, penilaian yang terdiri dari penilaian sikap, penilaian ketrampilan dan penilaian pengetahuan yang semuanya bersifat penilaian autentik, kadangkala terlihat rumit bagi beberapa guru di lapangan, dalam memaparkan hasil penelitian ini, peneliti bermaksud juga menampilkan hasil telaah dokumen mengenai penilaian pada kurikulum 2013 disandingkan dengan beberapa kondisi di lapangan yang ditemukan oleh peneliti.

Bentuk-bentuk penilaian dalam tiga ranah tersebut masing-masing dapat dipilih oleh guru sesuai dengan kebutuhan dalam melihat sejauh mana pencapaian siswa dan melihat perkembangan siswa, untuk mempermudah pemahaman mengenai bentuk-bentuk penilaian yang ada di kurikulum 2013, peneliti merangkum dalam bentuk tabel sebagai berikut :

Tabel 3.

Bentuk penilaian dalam kurikulum 2013

\begin{tabular}{|l|l|l|l|}
\hline No. & \multicolumn{1}{|c|}{ Pengetahuan } & \multicolumn{1}{c|}{ Ketrampilan } & \multicolumn{1}{c|}{ Sikap } \\
\hline 1. & Tes Tulis & Unjuk Kerja/Praktik & Observasi \\
\hline 2. & Observasi & Proyek & Penilaian diri sendiri \\
\hline 3. & Penugasan & Produk & Penilaian teman sebaya \\
\hline & & Portofolio & Penilaian Jurnal \\
\hline
\end{tabular}

Kenyataan di lapangan yang ditemukan oleh peneliti, yang pertama adalah memang bentuk variasi penilaian sikap dan ketrampilan yang dimiliki oleh guru sejarah dan sejarah Indonesia masih kurang, hal tersebut memiliki kaitan erat dengan perencanaan yang dimiliki tidak membahas hingga ke detail bentuk penilaian secara mendalam dan hanya mengubah isinya tanpa merubah bentuk penilaian yang ingin dipakainya. 
Dalam penilaian berbasis kurikulum 2013 pada bidang pengetahuan, guru hanya biasa menggunakan tes tertulis berupa ulangan harian dan penugasan, sedangkan untuk ketrampilan, guru biasanya mengambil nilai dari hasil presentasi (unjuk kerja) para siswa di depan kelas. Sedangkan untuk penilaian sikap, observasi menjadi satu-satunya bentuk penilaian yang digunakan.

Mengenai penilaian sikap yang dimiliki oleh guru, hampir semua informan menggunakan penilaian Jurnal (Anecdotal record) dimana para guru hanya menyiapkan daftar absensi dan buku nilai yang kosong serta memberikan penilaian dan mencatat langsung apapun kejadian yang melibatkan sebuah sikap yang positif maupun negative dari para siswa saat itu juga, dan nanti dalam penghitungan nilai sikap, catatan tersebut akan menjadi pertimbangan guru dalam memberikan nilai sikap kepada para siswa.

\section{Pembuatan Laporan Hasil Belajar Siswa}

Laporan hasil belajar siswa merupakan sebuah laporan pencapaian hasil kinerja siswa yang dibagikan di akhir semester. laporan hasil belajar menggambarkan nilai akumulasi pada semester berlangsung di sekolah tersebut. Perbedaan besar antara dua lokasi penelitian yaitu penggunaan aplikasi yang sangat berbeda, pada lokasi penelitian 1 yaitu SMAN 81 Jakarta, sistem penyusunan laporan hasil belajar yang disebut rapor, menggunakan aplikasi E-Rapor sedangkan pada lokasi penelitian 2, SMA Angkasa 1 Jakarta masih menggunakan aplikasi lokal yang berbasis Microsoft dan tidak dalam mode daring.

Proses pembuatan rapor pada SMAN 81 Jakarta dimulai dengan masuk kedalam jaringan intranet atau internet dengan menggunakan server lokal untuk intranet dan on-line (daring) untuk internet. Jaringan intranet yang digunakan di sekolah SMAN 81 Jakarta adalah 192.168.3.10.8080:erapor//SMA atau mengakses 118.97.89.251:2676 untuk mode daring bila mengerjakan di rumah.

Format rapor pada aplikasi E-Rapor memiliki komponen-komponen nilai yang mengacu pada penilaian di kurikulum 2013, nilai yang harus dimasukan para guru antara lain adalah :

a. Nilai kompetensi sikap spiritual/Kompetensi Inti 1

b. Nilai kompetensi sikap sosial/ Kompetensi Inti 2

c. Nilai kompetensi Pengetahuan pemahaman konsep/ Kompetensi Inti 3

d. Nilai kompetensi ketrampilan/Kompetensi Inti 4

Tahap pertama yang harus dilakukan guru adalah membuat rencana penilaian yang didalamnya guru harus menginput kompetensi dasar apa yang ingin dinilai dan kemudian menentukan bentuk tagihan yang akan 
dipakai, setelah input rencana penilaian, baik KI 1, KI 2, KI 3 dan KI 4 maka langkah selanjutnya guru harus menginput nilainya kedalam format yang sudah direncanakan sebelumnya.

Hasil penilaian pencapaian pengetahuan dan keterampilan dilaporkan dalam bentuk bilangan bulat (skala 0 - 100) dan predikat (D - A) serta dilengkapi dengan deskripsi singkat yang menggambarkan capaian kompetensi yang menonjol dalam satu semester. Predikat pada pengetahuan dan keterampilan dinyatakan dengan angka bulat dengan skala 0-100, ditentukan berdasarkan interval predikat yang disusun dan ditetapkan oleh satuan pendidikan.

Setelah menginput nilai pada sistem aplikasi E-Rapor, para guru kemudian menyelenggarakan rapat pleno untuk memutuskan ketuntasan belajar peserta didik beserta dengan segala pertimbangannya, sayangnya peneliti tidak memperoleh data terkait pelaksanaan rapat pleno baik di lokasi penelitian 1 maupun 2, hal tersebut dikarenakan ada beberapa hal rahasia yang merupakan konsumsi internal sekolah yang bersangkutan.

SMA Angkasa 1 Jakarta merupakan salah satu sekolah di lingkungan DKI Jakarta yang belum menggunakan aplikasi E-Rapor, prosedur penyusunan rapor masih menggunakan aplikasi manual yang tidak terhubung ke Dapodik. Penyusunan rapor di SMA Angkasa 1 Jakarta telah menggunakan format yang terkomputerisasi yang merupakan hasil kerja dari tim admin/staff kurikulum SMA Angkasa 1 Jakarta.

\section{PENUTUP}

Kesimpulan dari penelitian ini adalah, masih rendahnya tingkat implementasi kurikulum 2013 di lokasi peneltian, terlihat dari tidak lengkapnya perangkat pembelajaran yang dibuat dan dimiliki guru sebagai pedomannya dalam melaksanakan program pembelajarannya, selain itu pada sisi pelaksanaan pembelajaran terlihat telah menerapkan pendekatan saintifik walaupun tidak teridentifikasi model pembelajaran yang spesifik dalam melaksanakan pembelajaran di kelas karena kurang mendalamnya pemahaman mengenai model pembelajaran dalam kurkulum 2013.

Pelaksanaan evaluasi pembelajaran juga belum terimplementasikan secara sempurna karena para guru hanya melakukan satu teknik pengambilan data penilaian sikap dari sekian banyak teknik pengambilan nilai sikap bagi siswa. Penilaian pengetahuan dan ketrampilan banyak menggunakan teknik penilaian tes tertulis, pembuatan makalah, presentasi/unjuk kerja, dan kuis.

Kesimpulan lain adalah bahwasanya di lokasi penelitian, perbedaan antara mata pelajaran sejarah dan sejarah Indonesia hanyalah sebatas materinya yang berbeda, tidak adanya perbedaan strategi, metode dan 
model yang dilakukan guru di lokasi penelitian dalam melaksanakan pembelajaran untuk dua mata pelajaran. Hal tersebut disimpulkan oleh peneliti dikarenakan pemahaman yang masih rendah terhadap tujuan pembelajaran dari dua mata pelajaran tersebut.

Implikasi dari penelitian ini adalah terdeskripsikannya pelaksanaan pembelajaran sejarah dan sejarah Indonesia di kotamadya Jakarta Timur, khususnya mengenai keadaan dan persepsi guru terhadap perencanaan pembelajaran, pelaksanaan pembelajaran di kelas, penilaian dan evaluasi pembelajaran serta pembuatan laporan hasil belajar siswa sehingga mungkin dapat digunakan dalam penelitian lebih lanjut mengenai pembelajaran sejarah di SMA.

\section{DAFTAR PUSTAKA}

[1] S. Hamid Hassan. 2012. Pendidikan Sejarah Indonesia,Isu Dalam Ide Dan Pembelajaran. Bandung: Rizqi Press.

[ 2 ] Martin Hunt. 2007. A Practical Guide To Teaching History In The Secondary School. New York : Routledge

[3] Kementerian Pendidikan dan Kebudayaan. 2012. Dokumen Kurikulum 2013. Jakarta: Kemendikbud RI. 